\title{
ISSUES AND CHALLENGES FOR DEVELOPING CORPORATE SUKUK: LESSONS FROM AN INDONESIAN CASE STUDY
}

\author{
Nasution Lokot Zein, Researcher \\ Financial Sector Policy Center, Fiscal Policy Agency, Ministry of Finance, Indonesia \\ E-mail: lokotzein.nasution@gmail.com
}

\begin{abstract}
This research is trying to find the issues, challenges, and strategies development of corporate sukuk in Indonesia. This objective arises because the level of supply and demand for corporate sukuk in Indonesia is still prolonged. This case in Indonesia is almost similar to cases in some countries, especially in Asian countries that are making efforts to develop sukuk market. Based on the method of mapping and root problem analysis, this study found three problem structures inhibiting the growth rate of corporate sukuk in Indonesia. The first stage of the problem is a surface issue, namely: concerns of potential double taxation; lack of understanding from investors; lack of knowledge of the issuer; unparted investor base; less liquid in the secondary market; very complex publishing documents; the contract variation remains unclear. Seven issues of this first phase are caused by five sources of the second issue, namely: there is still the required information regarding the issuance of sukuk is asymmetric; unavailability of supporting profession; unavailability of supporting industries; costly issuance costs; complex sukuk structures. The third stage of the problem causes the first and second problems, also called the root of the slow growth of corporate sukuk in Indonesia, namely: low socialization and education and the limited human resources of capital market actors concerning sukuk. On the three structures of the problem, the proposed development strategy sukuk corporations in Indonesia consist of two priority suggestions, namely: increasing socialization and education on corporate sukuk and clarify rules on corporate sukuk, related to rules on supporting institutions, contract structure, human resources, and administration. This result can be a reference to create the right strategy to encourage the growth of corporate sukuk in the long term. This research is also beneficial as a pilot development of corporate sukuk in several countries with cases and characters that are almost similar to Indonesia.
\end{abstract}

\section{KEY WORDS}

Corporate sukuk, corporate growth, socialization, education, sukuk rules.

Sukuk is an Islamic security that is often translated as the obligation of sharia, namely the representation of asset value with sharia bonds, or also referred to as Islamic investment certificates (Saeed \& Salah, 2014 ). Sukuk is also interpreted as a private bond as securities issued by sharia principles and concepts approved by the Shariah Advisory Board (Hanefah, Noguchi \& Muda, 2013; Hosen, 2017). AAOFI (2015) describes sukuk as a certificate of equal value representing an integral part in the possession of a tangible asset, benefit or service, or the ownership of an asset of a particular project or investment activity, which occurs after receipt of the sukuk funds, closing of the reservation and the funds received are utilized in accordance with the objective issuance of sukuk. The majority of sharia in Indonesia, the Indonesian Council of Ulama through DSN (2004) defines sukuk as long-term security based on sharia principles issued to issuers of sharia bonds obliging issuers to pay revenues to sharia bondholders in the form of profit/ margin/fee and repay the bond fund at maturity.

Upon its characteristics or characteristics, sukuk has been in demand by a variety of capital market actors at the global level. In the last decade, the development of sukuk has grown very rapidly and is increasingly popular. The IIFM report (2017) states that total global sukuk emissions during 2016 reached USD 88.4 billion, representing an increase of $44 \%$ of total emissions in 2015 amounting to USD 61 billion. The rapid increase in volume during 
2016 was influenced by stable emissions from Asia, the Gulf Region, and Africa. Of the two types of sukuk (state sukuk and corporate sukuk), whose rate of growth is very fast at the global level is a type of corporate sukuk. The countries with the highest rates of sukuk issuance on a global basis are Malaysia, Saudi Arabia, Bahrain, Indonesia, Brunei, UAE, Qatar, and Turkey (IIFM, 2017).

Although corporate sukuk at the global level has a rapid growth rate compared to the state sukuk type but its development in Indonesia is still very slow. According to the data of Islamic Capital Market (2018), the number of outstanding sukuk in Indonesia in 2017 recorded as many as 60 series, with its value of Rp. 14.31 trillion. Compare with the type of sukuk country where the outstanding is only 53 series but with a value of Rp. 485.44 trillion. This figure shows that the development of corporate sukuk in Indonesia is still not optimal. The case of slow growth sukuk corporations in Indonesia indicates that there is a wide range of problems attached to the sukuk corporate type. Given the importance of the role of sukuk for economic funding, then overcoming the problem of the slow rate of growth of sukuk, especially the type of corporate sukuk becomes very important to do.

Based on the above background, the purpose of this study is divided into two, namely: (i) first is to map the issues and challenges for the implementation of the development of corporate sukuk in Indonesia; and (ii) the second is to formulate a corporate sukuk development strategy in Indonesia. Both of these objectives are important to be answered in order to contribute to empirical studies and their contribution to the literature, particularly with regard to issues embedded in corporate sukuk and its development strategies.

To answer two goals research, the systematics of writing in this study is divided into six stages. First is the background, the two will be explained about the theoretical base, the third is the conceptual framework, the fourth is the research method, the fifth is the discussion, and the sixth is the conclusion and suggestion. The sixth systematics is a unity that serves a comprehensive and structured analysis.

\section{LITERATURE REVIEW}

Why at Global Level Corporate Sukuk Have Rapid Growth Rates? The rapid growth of corporate sukuk at the global level indicates that corporate sukuk is an instrument that has several advantages. Theoretically, this excellence corporate sukuk is included in the realm of sukuk excellence in general. AAOFI (2015) try to trace the sukuk superiority of its structure, sukuk is basically a certificate of the same value as the number of shares not divided into the ownership of a set, the material and the tangible service, or as a particular project or special investment activity but is valid after receiving the value sukuk, subscription closing and use of funds received for the purpose of issuance of the sukuk. This explanation is enriched by the opinion of Rusydiana (2012), that sukuk is a certificate of equal value representing a share of total ownership of tangible assets, benefits and services, asset ownership of a project, or ownership in a business activity or special investment. Some of the characteristics of this sukuk have driven the rate of supply and demand for sukuk growing rapidly in the global level, especially corporate sukuk, where the average per year grows more than 30 percent (Zin et al., 2011). The rapid growth of corporate sukuk at the global level is supported by the performance of the company as the issuer is considered to perform very well and trusted by the public who plays as investors.

According to Afshar (2013), sukuk (especially the corporate sukuk type of an honest issuer) for investors is very profitable because of the right to certain ownership because sukuk is an instrument asset-based. According to Saeed \& Salah (2014), sukuk is very profitable because of its equity-based characteristics, in contrast to debt bonds. The opinion of Saeed \& Salah is supported by Samaoui \& Nechi (2017), that sukuk excellence lies in the absence of a debt base since sukuk is issued on the basis of Islamic moral or jurisprudence (figh) or principled economic activity in Islamic law (fiqh al-mu'amalat). Sukuk based terminology ih $\mathrm{fi} q$ is the object of the contract of sale or lease and other forms in accordance with the contract made (Afif, 2014). A study from Hanefah, Noguchi \& Muda (2013) found that the issuance of sukuk in each country must be guaranteed by each Sharia Council which 
is in charge of controlling and ensuring the sukuk's compliance with sharia guidelines in each country concerned. It aims to enable a number of capital market participants in order to raise capital in a consistent manner with Sharia principles.

The superiority of sukuk versus conventional bonds basically lies in its idealistic condition which puts more emphasis on morale and profit by avoiding transactions prohibited in Islamic jurisprudence (Saeed \& Salah, 2014). The existence of the advantages of moral and profitability aspects on the Sukuk much proved that sukuk profit is more profitable than conventional bonds. Another explanation is also conveyed by Dewi (2011), which states that the sukuk advantages compared to other convention bonds lies in its structure that is based on real assets. The sukuk holder is entitled to the share of income generated from the sukuk assets in addition to the rights of the sale of the sukuk assets. Research from Smaoui \& Nechi (2017) proves that sukuk is indeed more promising in the rate of return and financial security greater than conventional bonds. This finding is supported by research results from Zin et.al (2011), that sukuk has a number of objectives that enable market participants to raise capital in a consistent manner $t$ with sharia principles while at the same time expanding the investor base and offering wider investment opportunities. According to Hanefah, Noguchi \& Young (2013), sukuk are very open and beneficial for all market participants and investors regardless of background, beliefs, and religion respectively.

Do Risks Attached to Sukuk Influence Significantly on Low Level of Supply and Demand? Although sukuk has several advantages, it also has some risks that are similar to the conventional bond risks. Theoretically, the risks inherent in sukuk are basically divided into two sides, namely from the supply side and from the demand side. From the supply side is the risks that arise because it is more caused by issues inherent to issuers and regulations associated with the issuance of sukuk. While the demand side is the risks that arise because more caused by investor concerns. This is supported by a statement from Jarkasih \& Rusydiana (2011), that parties who play a direct role in the growth of sukuk can be divided into two sides, namely the supply and demand side. From the supply side, several parties involved are publicly listed companies/issuers as sukuk issuers and underwriters as parties working with publicly-listed companies/issuers in sukuk offerings. Meanwhile, from the side of demand, the parties involved are investors, both individual investors, and institutions (institutions).

Decisions from the supply and demand sides can be an obstacle to the growth rate of sukuk due to the inherent limitations of sukuk, both internal and external. Some of the limitations are: (i) lack of application related to structural innovation; (ii) there is still a need for understanding from market participants because the socialization of sukuk is still lacking; (iii) the low level of government commitment due to regulatory aspects remains unclear; (iv) the legal framework remains minimal; (v) lack of support of human resources who understand or expert in the field of sharia capital markets; and (vi) there are still diverse challenges such as liquidity risk, asymmetric information, covenant and sukuk structure, and underlying principle. In addition to these six limitations, the sukuk may also risk generating a default.

Ahmad, Daud \& Kefeli (2012) argued that the development of sukuk is strongly influenced by some of the risks attached to sukuk, which also significantly influence the decisions of issuers and investors to choose sukuk. Based on the results of research from Endri (2007), some sukuk risks can be interpreted as issues still attached to sukuk, such as low socialization to investors, opportunity cost, and liquidity aspect, to less favorable regulations or legislation. The research result of this Endri temua $\mathrm{n}$ reinforced by the results of the Goddess (2011), that the slow rate of growth of the sukuk, in particular, the type of corporation more due to regulatory factors and market conditions are less stable. According to the research of Haron \& Ibrahim (2012), the condition of the less supportive environment is very influential significantly against the incentives of firms in issuing and buying corporate sukuk.

The explanation above confirms that the risks inherent in sukuk have a significant effect on the supply and demand levels. However, sukuk still believed to be safer than conventional bonds, because theoretically, character sukuk is to transfer ownership of the 
underlying asset to the holder, which in turn will gain an upper Protects the asset ownership (Zakaria, Isa \& Abidin, 2012).

\section{CONCEPTUAL FRAMEWORK}

The conceptual framework in this study is based on the fact that the slow rate of growth of corporate sukuk in Indonesia is still slow. This condition is inversely proportional to the growth rate of corporate sukuk at a global level which is more dominant than the growth rate of sukuk country. Based on theoretical studies, the growth rate of sukuk, both corporate and sukuk countries basically it still faces some constraints, especially from the risks that are still attached to sukuk, both from the content of the supply and demand.

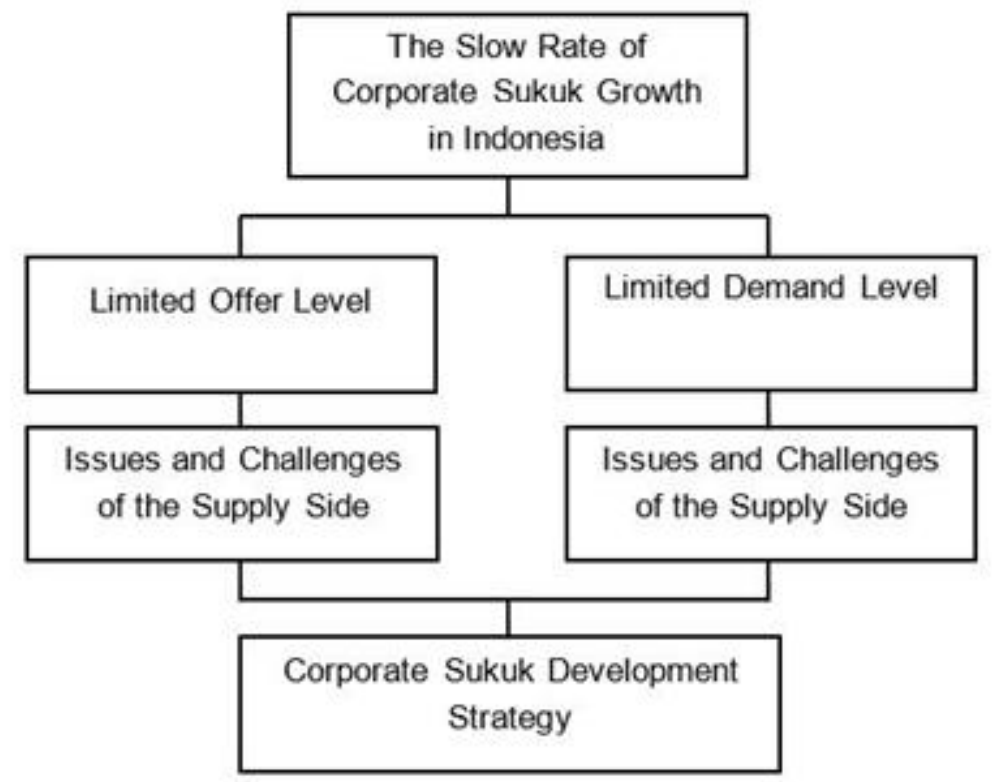

Figure 1 - Conceptual Framework

From the supply side, several parties involved are issuers and underwriters, while in terms of demand are investors. On the issue of sukuk both in terms of supply and demand, then both sides will be parsed issues and challenges. Therefore, it is necessary to find a way out from both supply and demand side so that the growth rate of corporate sukuk can run optimally. This strategy is expected to be proliferation as well as a reference to comparative studies for the development of corporate sukuk in countries with characteristics similar to Indonesia.

\section{METHODS OF RESEARCH}

This research used qualitative technique of mapping (mapping research) and root cause analysis (root cause analysis). Qualitative approaches are considered to be best suited for being able to find, explore, describe, and explore field issues for identification and evaluation purposes. Qualitative exploration in this research is done through in-depth interviews (depth interview) with the characteristics of cross-checking, confirming, deepening, and triangulation are carried out continuously until the data becomes saturated. Data saturation levels continue to be made in order to ensure that the excavated data is completely valid. The in-depth interviews undertaken in this study were approached with the concept criterion-based selection, namely selecting informants through the assessment of competence and its capabilities that really meet the criteria to be used as informants in digging the research data. Details in conducting research methods are as follows: 
Characteristics of Informants. Total informants in this study are not based on minimum quota because this research is qualitative. In qualitative research, there is no limit or the minimum number of informants, but the existing informants must meet the qualification standards representative of the case under study. Of the total informants obtained, they can be divided into 8 categories of informants, namely: (i) investors who are new sukuk or less than 2 years plunge in the market sukuk; (ii) sukuk investors who have long been the perpetrators of sukuk; (iii) the issuer has issued sukuk; (iv) issuers that have not issued sukuk; (v) the Financial Services Authority; ( $v$ i) and Financing Risk Management Directorate, Ministry

(vii) Underwriter; and (viii) Directorate General of Taxes of the Ministry of Finance.

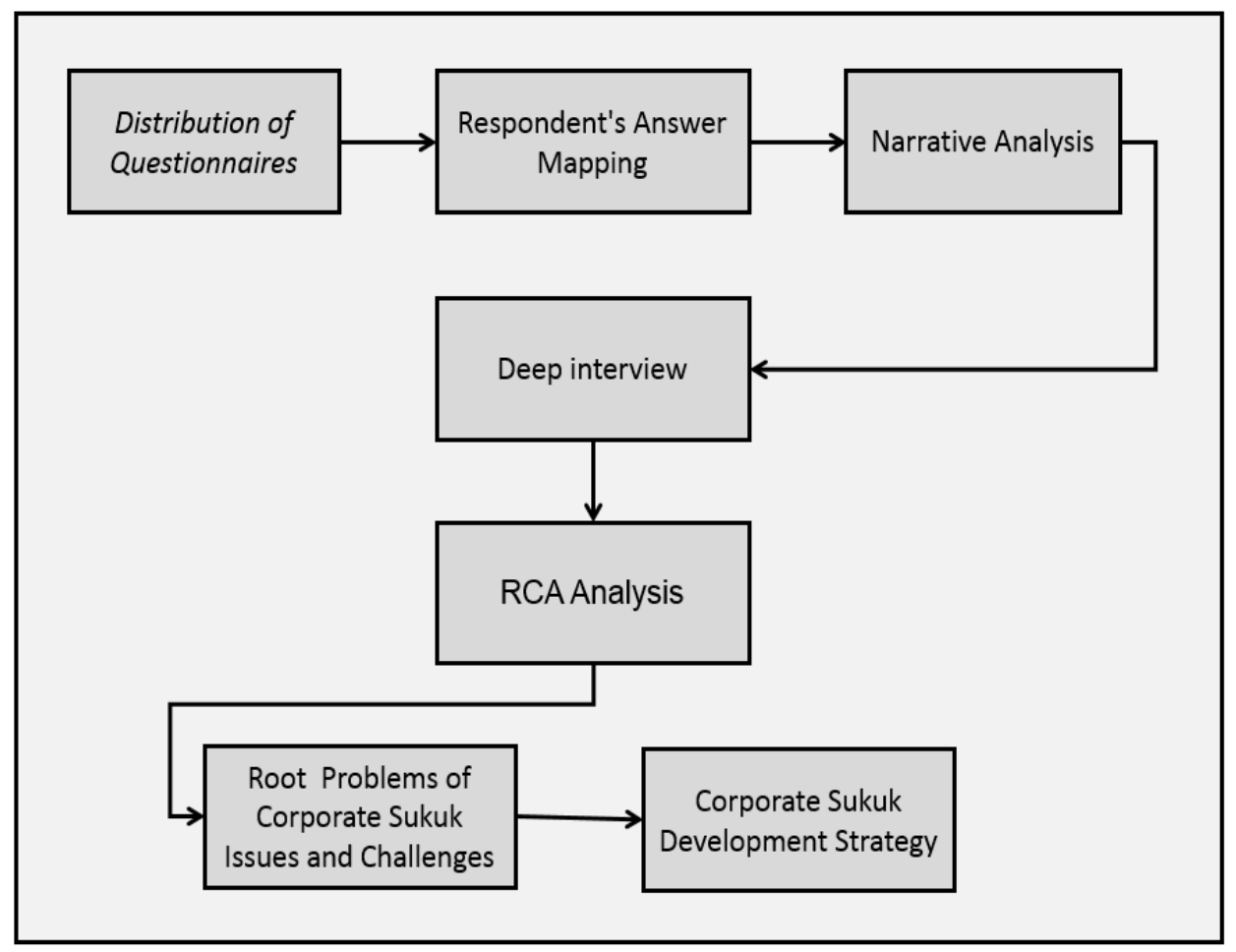

Figure 2 - Flow of Research Methods

How to Dig Data. After determining the criteria of informants, the researcher then spread the questionnaires to each informant. After the questionnaire was answered by each informant, then the informant will then return the questionnaire to the researcher along with the result of the answer. Researchers then sort out the answers of informants by using the mapping system (mapping research). This mapping is very necessary considering the answers of various informants with irregular patterns (random). Components performed in mapping activities includes 3 (three) stages, namely: (i) data reduction; (ii) presentation of data; and (iii) conclusions. The first is data reduction, the process of selecting and focusing the research through a rigorous selection of the focus that will be studied further. The second stage is the presentation of data, namely the process of organizing information systematically in order to obtain conclusions as research findings. While the third stage is the conclusion of the mapping results, which are drawn during data collection, but nature is still tentative so it is necessary to continue to verify the data, especially further discussion with each informant. To deepen the results mapping, then the next step is to do an in-depth interview (in-depth interview) in order to cross-check and experience information from each informant.

Analysis Method. To analyze the results of the field, then used Root Cause Analysis or RCA. RCA definition is a method to find the root of the problem of the issues inherent in the sukuk corporations, both in terms of supply and demand. RCA analysis seeks code between the narrative so you can find the root of the problem or a "major factor" growth inhibiting the 
rate of corporate sukuk in Indonesia. The RCA system in this study was prepared based on causal analysis to find the "main factor" of the problem of the growth rate of corporate sukuk in Indonesia. Technically, RCA in this research is done with 7 (seven) stages, namely: (i) identifying the main problem faced by market players in relation to activities related to corporate sukuk; (ii) identify the factors causing the problem; (iii) categorize causes and identify cause levels; (iv) identify the cause of the drivers of the problem; (v) determine the expectations to be addressed to address the problem; (vi) prioritize the causes of the most pressing issues; and (vii) prioritize the most effective and realistic expectations to achieve. From all the flow of the research method, it can be illustrated as in Figure 2.

\section{RESULTS AND DISCUSSION}

Based on the questionnaires were followed up by in-depth interviews (in-depth interviews), found a variety of responses from the informant who later filtered based on the priority of the answer (sequence) given by the informant. This filter is presented in Table 01. After screening based on mapping analysis, it is found that the problem of the slow growth rate of corporate sukuk in Indonesia is caused by 3 sides, namely regulation side, supply side and demand side. This finding adds to the results of previous research which mentions that the factors inhibiting the growth of corporate sukuk only focused on the supply and demand side.

Table 1 maps that each of the informants has responded in the highest order. Most answers are given by categories of investor informants, followed by securities underwriters, issuers, issuers, and the tax office. Of the three sides, the domains revealed by informant most are the supply side of 8 answers, followed by the regulation side of 7 answers, and the demand side as many as 4 answers. This mapping indicates that the problems inhibiting the growth rate of corporate sukuk in Indonesia are dominated by the supply side. This mapping results support the findings from Dewi (2011), which the obstacle to the development of corporate sukuk issues in Indonesia is caused by a problem issuer (the supply side).

Based on Table 01, issues and challenges from the supply side can be mapped to $8 p$. Based on in-depth interviews, 8 of these issues and challenges can be simplified into 3 major issues, namely: (i) still lack understanding of the issuers to the characteristics of sukuk; (ii) there are still limited human resources of capital market players; and (iii) still not mapped the investor base. These three issues already represent 12 issues and challenges from the supply side as listed in Table 1.

Lack of knowledge and Understanding of Issuers Against Sukuk. The average informant gave an answer that the issuers have not really understood the characteristics of sukuk so that the company has not intended to issue sukuk. This finding is in accordance with the results of research by Jarkasih \& Rusydiana (2009) that the lack of knowledge and understanding of issuers is still a major problem in issuing sukuk corporations in Indonesia. Bapepam (2012) and Kurniawati (2015) also found that one of the factors inhibiting the lack of corporate sukuk issuance due to lack of the issuer's knowledge of the sukuk.

When referring to the results of Dewi's research (2011), the lack of understanding of issuers in principle can be mapped into two issues, namely: (i) the issue of lack of understanding, namely the lack of understanding of issuers concerning sukuk; and (ii) averse to risk issues, i.e. for companies that have never issued, sukuk is a new instrument so it takes special consideration. Abdo (2014) found that the average issuers are still reluctant to seek to understand sukuk because the opportunity cost incurred is still too high. While Afshar (2013) proves that the average issuers are still very careful to issue sukuk because they have not really understood the potential demand for sukuk is actually very high. While Siskawati (2010) states the limited issuance of sukuk due to the issuer's lack of understanding not only in terms of the number of issuances, but also the variation of tenor and type of contract. In addition, issuers are also very limited to know all the information about the sukuk trading corporation in the secondary market. 
RJOAS, 2(74), February 2018

Table 1 - Mapping Results (Mapping) Answer Informant Factors inhibiting the rate of Corporate Sukuk Growth

\begin{tabular}{|c|c|c|c|c|c|}
\hline No & $\begin{array}{c}\text { Category } \\
\text { of Informant }\end{array}$ & Answer with Highest Score & $\begin{array}{l}\text { Problems } \\
\text { of the Supply Side }\end{array}$ & $\begin{array}{c}\text { Problems } \\
\text { of the Demand Side }\end{array}$ & $\begin{array}{c}\text { Problem } \\
\text { of Regulation Side }\end{array}$ \\
\hline 1 & Investor & $\begin{array}{l}\text { Not knowing about sukuk as the complement of conventional obligation } \\
\text { yet. } \\
\text { The Availability of information on sharia capital market is still limited } \\
\text { Limited liquidity in the secondary market } \\
\text { The regulations on sukuk remain unclear } \\
\text { Lack of socialization and education about the contracts to investors } \\
\text { Lack of socialization and education about the contracts to investors } \\
\text { Low contract and diversity of sharia products } \\
\text { Treatment of taxation on sukuk is still unclear }\end{array}$ & \multirow{5}{*}{$\begin{array}{l}\text { Lack of socialization and } \\
\text { education about the } \\
\text { contracts to investors } \\
\text { The existence of cost of } \\
\text { funds } \\
\text { Variations in the contract } \\
\text { and sukuk structure are } \\
\text { limited } \\
\text { Related costs of issuance of } \\
\text { sukuk } \\
\text { Unavailability of supporting } \\
\text { profession } \\
\text { The narrowness of } \\
\text { information disclosure is still } \\
\text { required related to the } \\
\text { issuance of sukuk } \\
\text { VAT imposition constraints } \\
\text { on the transfer of beneficial } \\
\text { rights to underlying assets } \\
\text { Not optimal socialization and } \\
\text { education about the } \\
\text { contracts to the issuer }\end{array}$} & \multirow[b]{2}{*}{$\begin{array}{l}\text { The majority of investors do } \\
\text { not know about the sukuk } \\
\text { as a complement of } \\
\text { conventional bonds }\end{array}$} & \multirow{3}{*}{$\begin{array}{l}\text { Availability of information on } \\
\text { sharia capital market is still limited } \\
\text { The accounting standards of } \\
\text { governing sukuk is still weak } \\
\text { The regulations on sukuk remain } \\
\text { unclear } \\
\text { The tax treatment of sukuk is still } \\
\text { unclear; }\end{array}$} \\
\hline 2 & Emiten & $\begin{array}{l}\text { Cost of funds (rewards to investors) } \\
\text { The absence of other supporting industries such as tafakul, sharia } \\
\text { mutual funds, multi finance sharia and others } \\
\text { The tax treatment of sukuk is still unclear } \\
\text { The tax treatment of sukuk is still unclear }\end{array}$ & & & \\
\hline 3 & $\begin{array}{l}\text { Prospective } \\
\text { Issuers }\end{array}$ & $\begin{array}{l}\text { Related costs of issuance of sukuk } \\
\text { The condition of domestic Islamic finance industry has not developed } \\
\text { rapidly and has not been supporting to issue sukuk } \\
\text { The absence of competent capital market support profession in the field } \\
\text { of Sharia capital market } \\
\text { The tax treatment of sukuk is still unclear }\end{array}$ & & $\begin{array}{l}\text { Limited liquidity in the } \\
\text { secondary market } \\
\text { Low market in absorbing } \\
\text { sukuk }\end{array}$ & \\
\hline 4 & Underwriter & $\begin{array}{c}\text { The liquidity of transactions in the secondary market is still limited } \\
\text { Potential low market in absorbing sukuk } \\
\text { The investor base on certain contracts is not yet mapped } \\
\text { The tax treatment of sukuk is still unclear } \\
\text { The unclear rules of OJK governing the issuance of sukuk } \\
\text { The complexity of sukuk issuance documentation } \\
\text { The narrowness of required information disclosure related to the } \\
\text { issuance of sukuk }\end{array}$ & & $\begin{array}{l}\text { The low level of contract } \\
\text { and diversity of sharia } \\
\text { products }\end{array}$ & $\begin{array}{l}\text { Islamic finance industry has not } \\
\text { developed rapidly and has not } \\
\text { been support to issue sukuk } \\
\text { The complexity of sukuk issuance } \\
\text { documentation }\end{array}$ \\
\hline 5 & $\begin{array}{l}\text { Directorate } \\
\text { General of } \\
\text { Taxation }\end{array}$ & $\begin{array}{l}\text { VAT imposition constraint on transfer of beneficial rights over } \\
\text { underlying assets } \\
\text { Not optimal socialization and education about sukuk contract } \\
\text { Unclear accounting standards governing sukuk }\end{array}$ & & & \\
\hline
\end{tabular}

Source: Primary Data Processing, 2017. 
Ascarya (2010) argued that the lack of understanding of issuers is not solely from the corporation's lack of availability of human resources who understand about the Sharia capital market, but also due to limited trading instruments. According to Kurniawati (2015), this issue becomes a determinant factor as an obstacle to the development of the Sharia capital market in Indonesia. But uniquely, the investigation of Saad, Mamat \& Mohamad (2014) who conducted a study in Malaysia found that the knowledge of issuers coming from state enterprises (SOEs) is better than private companies. The results of the research by Smaoui $\&$ Nechi (2017) also reveal that the ignorance of prospective issuers against sukuk makes them look for short-term securities, which is actually less in line with the balance sheet side of the company. Whereas according to Zakaria, Isa \& Abidin (2012), symmetrical sukuk market information is needed by issuers in order to encourage efficient and indispensable resource allocation for the growth of the financial sector. This finding may be a lesson of the importance of socialization and education of the private issuers.

There are still limitations of human resources of the Capital Market participants. Several informants mentioned that the slow rate of growth of sukuk is due to the limited human resources of capital market players. These findings may complement the results of OJK (2015) research that the majority of issuers who have not issued sukuk claim to know about sukuk but are less well understood, especially related to underlying assets, contracts or structures that can be used on sukuk due to human resource limitations. OJK (2015) also mentioned that the issuer's lack of understanding is caused by the lack of human resources who understand or expert in the sharia capital market. So far, the issuer's HR is still the category of expert actors in the field of conventional capital market. This problem becomes risky, given the availability of human resources who understand the Sharia capital market is very important to determine the issuer's decision in dabbling in the market sukuk (Purwaningsih, 2013).

Hosen's finding (2016) explains that the ignorance of the sukuk market participants against the sukuk itself is very risky to distort the market information sukuk so it can be very asymmetric (asymmetric information). This makes the sukuk instrument on the surface is in accordance with the principles of sharia but essentially still not because it is still below standard. The limited human resources of market participants to sukuk are criticized by Zulkhibri (2015) for making sukuk practice able to imitate the practice of conventional instruments. In addition, sukuk pacts can also become less transparent with regard to documentation and rights and obligations of various parties in the sukuk market. Therefore, we need more knowledge of competent human resources for some sukuk structures require complex knowledge level. This statement is reinforced by the results of the study of Ahmad, Daud \& Kefelia (2012), which finds that low human resources of sukuk market participants can reduce the participation of many investors who are accustomed to face with conventional bond products that are well ordered.

Research of Haron and Ibrahim (2012) states that the conditions at the global level are already very possible because of the availability of competent human resources in the field of securities, so it can create a lot of companies to enrich its capital structure and attracting investors to the sukuk. According to Fatah (2011), the condition at the global level is inversely proportional to Indonesia, because in the country the quality of human resources is still low. These findings are reinforced by Kayo \& Kimura (2011), that the development of corporate sukuks in a country is not only influenced by the capital structure or financing decisions of a company, but more determined by the HR factor of the perpetrators. This is as exemplified by the discovery of Sole (2008), which the rapid growth rate of corporate sukuk in the Gulf countries is strongly influenced by the business environment and human resources are good and specialized.

Base Investor is Still Not Available. Based on the results of the mapping, the informants stated that there is still a problem of the unpublished investor base. These limitations make issuers reluctant to issue sukuk for fear quiet enthusiasts because the investor base is still unclear. In addition, it is also supported by a base mapping of the issue that has not been an investor in the contract-specific contract. Investor base that is not mapped is very influential because the issuer is taking no chances with the issuance of new instruments that prefer to 
publish an existing contract. According to the FSA (2016), a database of investors is highly correlated to the level of sukuk deals that have a variety of contract respectively. Contracts very important in being a basis for the development of sukuk. For issuers, the investor base can provide information about the absorption capacity and the ability of the market (Saad, Mamat \& Mohamad, 2014). the investor base that is not mapped according to Afshar (2013) is very risky so sukuk cannot be developed because of the potential local investors is actually very high, so this makes the external resources of sukuk enthusiasts are not allocated as efficiently.

Based on Table 1, issues and challenges of the demand can be mapped to $4 \mathrm{p}$. Based on analysis of in-depth interviews, four issues and challenges can be simplified into three major issues, namely: (i) lack of understanding of investors on the securities; (ii) the limited liquidity of sukuk in the secondary market; and (iii) the low variation of the contract and the structure of sukuk. The third issue is already representing 4 issues and challenges in terms of demand as listed in Table 01.

Investors are still lack of knowledge about Sukuk. The issue of inhibitors of the demand is more focused on several variables attached to the investor. The majority of investors have not been so understanding about corporate sukuk making the investor might not think to invest their money in sukuk instruments. The impact of the limited knowledge of these investors is the low level of demand for sukuk sharia capital market. According to Fatah (2011), the lack of knowledge of sukuk investors against a tendency of investors often compare the benefits offered by conventional bonds is actually very asymmetric. These results are enriched by the opinions Kurniawati (2015) that the limited demand for sukuk in the Islamic capital market due to public understanding is still so low that in fact, they are as a potential investor. This statement is reinforced by Afshar (2013), that the people who are interested in sukuk are actually very high because they really wanted a decent return at the same level in accordance with the principles of Sharia. Jarkasih \& Rusydiana (2015) asserts that the lack of knowledge and understanding of the community has always been a major issue in nature of Islamic economic development, including in the Islamic capital market instruments such as sukuk, although the potential of its very big.

According to Saad, Mamat, and Mohammed (2014), the lack of community's knowledge towards sukuk is strongly influenced by the model of regulation, in particular, less comprehensive socialization. Whereas investor knowledge is needed to assist them in making judgments about the prospects of profits (Zakaria, Isa \& Abidin, 2012). Some countries indicate that the bonds created a rating system is still very poor, so the impact on public ignorance of how to assess issuers prospectively. As in conventional bonds, investors who intend to invest in sukuk should also take into account the sukuk ratings (Jaffar, 2010). The issue of the lack of sukuk knowledge according to Sole (2008) contributed to the problem of the use of sukuk which have not easy because of the necessary process of adaptation to long associated the use of the principles of sharia. Another impact that can be generated is the low capital accumulation issuers, narrowing the investor base, and little opportunity for an investment offer to the public (Zin, et.al, 2011). Some of these conditions make sukuk as an instrument that is less competitive and less able to provide protection to the issuer due to the low level of demand due to the lack of knowledge of investors (Hosen, 2016).

Liquidity Bonds in the Secondary Market is Still Limited. The next problem that the informants complain about is the limited liquidity in the secondary market. For investors, the dominant factor that influences them to buy corporate sukuk is the sukuk liquidity. The results of the Abdo (2014) which is supported by Putri (2015) explains that sukuk still face the risk of the mixture and one resulting risk of the sharing arrangement is liquidity factor. According to Zulkhibri (2015), the issue of liquidity almost always happening even though the sukuk market has grown rapidly, one of the cause is due to the lack of standardization and concerns will be less protection for investors. The liquid sukuk indicates that the sukuk market is growing well, causing other companies to be interested in issuing sukuk, and vice versa (OJK, 2015). This is reinforced by Zaherr \& Wijnbergen (2013) that low liquidity causes sukuk less desirable and difficult to develop. When the condition of the secondary market is 
not liquid, the transaction becomes not much done. Investors tend to buy and hold due to the availability of relatively few sukuk instruments that are difficult to recover when needed (Dewi, 2011).

Tariq (2004) argues that the limited sukuk liquidity in the secondary market is a major constraint to the demand for sukuk, in addition to the issue of asymmetric information, underlying principle, sukuk structure, and competitiveness. Other than that, the low level of liquidity resulted in ownership transfer mechanism sukuk becomes inefficient. According to Zakaria, Isa \& Abidin (2012) and Sole (2008), low liquidity can result in instability of financial institutions and make risk management sukuk becomes low. If low liquidity persists in the long run, it is risky to make sukuk always unattractive to market participants (Saad, Mamat \& Mohamad, 2014). This statement is supported by the research results of Smaoui \& Nechi (2007) by taking samples in the 42 countries that prove that lack of liquidity correlated positively and significantly associated with difficulty in the development of sukuk in the long term. According to Zin et.al (2011), the difficulty of the sukuk development has a high risk to make less competitive sukuk environment and make the financial system less stable.

Variation of Agreement and Sukuk Structure is Still Low. The last problem from the demand side is the low variation of contract and sukuk structure. This has an impact on the low level of demand as investors require more varied contracts and structures. The more variety of contracts and sukuk structures, it will provide a variety of options for investors who want to invest. The increasing variety of contracts and sukuk structures also adds investor confidence to the sukuk. But the current condition shows the narrowness of alternative investors in buying sukuk due to low contract variations. If the use of financial instruments (including the variation of contracts) is less developed, then the economic actors will increasingly increase their investment in sukuk (Kurniawati, 2015). The opinion of Kurniawati (2015) is also supported by the findings of Dewi (2011), that the current sukuk market is still covered by the limitations of the instrument, namely the small variation of the contract and the tenor. During this time the average issuance of sukuk still fixed on ijarah and mudharabah contract. This is supported by the findings from Jarkasih \& Rusydiana (2011) that the issuance of corporate sukuk in Indonesia has been the new average using mudharabah and ijara contracts. According to Fatimatuzzahra (2014), the limitations of the contract will be evaluated repeatedly by the investors. Limitations of the contract are valued as the risk of sukuk contained in the issuance of sukuk so that investors anticipate the issuance of sukuk and assume that the issuance of sukuk does not add value to the company.

The results of Abdoo (2014) found that cases in some countries with slow sustained growth rates have indicated the occurrence of sukuk risk due to homogeneous structures and contracts. This opinion is reinforced by Zaheer \& Wijnbergen (2013), that the sukuk face a mixture of risk and risk-sharing arrangements for the use of Islamic principles, liquidity, governance of law, and the variation of the contract. While research from Setyani \& Endri (2013) conducted in Indonesia outlines that the risk of sukuk is determined by how big the capacity of an issuer in offering a variety of contracts to investors. If the company concerned has a variety of different contracts, then the risk of the low demand for sukuk will not be faced, and vice versa.

Based on Table 1, issues and challenges from the regulation side can be mapped to 7 p. Based on the analysis of in-depth interviews, the 7 issues and challenges can be simplified into 2 major issues, namely: (i) lack of information on Sharia capital markets; and (ii) regulations regarding securities that are still unclear. Both of these issues already represent 4 issues and challenges from the side of the regulation as listed in Table 01.

Availability of Information Concerning Sharia Capital Market is Still Lacking. Basically, many market participants lack understanding of Sharia capital market information, especially corporate sukuk. Based on the results of in-depth interviews, parties who often lack understanding about sukuk instruments is the investor. According to some investors as research informants, socialization and education about sukuk-contracts are still very limited, whereas sukuk is a Sharia capital market instrument that has various types of contracts. These findings support the results of a review conducted by Bapepam (2011), that the lack of 
investor interest in investing in the capital market, including the effect of sharia due to lack of socialization related to the understanding of sukuk investment. Rusydiana (2012) argues that the emphasis on the lack of socialization is the lack of specific knowledge related to sharia capital markets, especially sukuk. According to Dewi (2011), market participants' ignorance about the characteristics of this sukuk is called as lack of knowledge, which is still a lack of knowledge owned by market participants.

Other information that has not been widely known is related to some risk of sukuk. Some of the average sukuk risks are not understood by market participants, such as the risk of returns, credit risk, exchange rate risk, price level risk, liquidity risk, and risk of sharia compliance. This is due to the low level of socialization and education compounded by the lack of supporting professions and supporting industries in the sukuk market which resulted in the sukuk market, especially corporate sukuk increasingly asymmetric. According to Fatimatuzzahra (2014), investors basically have not been familiar with the attributes attached to sukuk, such as contracts, profit sharing, and margin on sukuk. Whereas according to Huda \& Nasution (2007), investors in conducting transactions in the capital market based its actions on various information obtained. According to Fatimatuzzahra (2014), so far sukuk still considered as a bond used by investors in financing short-term needs or finance the debt. According to Dewi (2011), market participants' ignorance about the risk of sukuk is referred to as lack of understanding, which is still a lack of understanding of market participants regarding sukuk.

The Regulations on Sukuk Still Unclear. Informants who declare that the regulation concerning sukuk still unclear majority come from emiten and investor. These issues include the lack of good governance of the sukuk market. Poor market governance demonstrated by the unavailability of capital market supporting professionals who are competent in the field of Islamic capital markets, and the lack of supporting industries such as tafakul, Islamic mutual funds, finance companies sharia and others. This finding reinforces the results of Dewi (2011) research, that the weakness of the sukuk market is one of them is the absence of professions and supporting institutions and the preparation of operational book guidance. Yet according to research Saad, Mamat \& Mohamad (2014) in Malaysia, shows that the rapid growth rate of sukuk in the country is strongly influenced by innovation and good market governance. Malaysia has developed progressive sharia capital market regulation, pro investors and issuers with various incentives and innovative to ensure a stronger Islamic financial system.

In addition to market governance, the unclear sukuk regulations also relate to market conditions that are still very asymmetric. This condition affects the complexity of the document issuance of sukuk, because of the number of documents that must be prepared to face some risks that are not predictable (unpredictable). Regulators have not been able to arrange effective and efficient sukuk issuance documents. The high cost is due to the complexity of the documentation because it involves the agreement documents that must be made by notaries and legal consultants. There is a perception among issuers that the cost of issuance of sukuk is more expensive than the cost of issuing bonds. According to Utaminingsih (2008) and Fatimatuzzahra (2014), the complexity of sukuk documents makes market participants, especially issuers unable to achieve efficient financing. Meanwhile, according to Dewi (2011), the complexity of sukuk issuance documents makes investors tend to be conservative and prefer profit oriented and floating majority behavior, i.e. investors tend to consider profits without sharia principles.

The next finding that is still related to the complexity of the issuance of sukuk documents is the unclear standard of accounting governing sukuk. So far, the preparation of accounting standards has not provided clear and standard guidelines in accordance with the characteristics of sukuk as the effect of sharia. For example, mudharabah and musyarakah contracts do not require underlying assets, requiring different types of bookkeeping with sukuk contracts requiring underlying assets. Likewise, the absence of clear accounting standards has an impact on the difference of calculation for the result between the issuer and the investor. Unclear accounting standards have an impact on the poor estimation of benefits for market participants, for example, investors are difficult to predict profit, as well as for 
issuers. In addition, the unclear accounting standards governing sukuk also contributed to the rating of sukuk that had never been done. The sukuk rating in its calculations is heavily influenced by accounting standards such as liquidity, leverage, profitability, productivity, size, and solvency (Purwaningsih, 2013).

The cause-effect analysis is an exploration of the results of the Root Cause Analysis (RCA) method. The result of root problem analysis is the set of various problem factors found based on mapping analysis, from supply, demand, and regulation. The set of problems from these three sides is then coupled and summarized based on cause and effect analysis between problem factors. The findings of root cause analysis that causing the slow growth of corporate sukuk in Indonesia are as follow in Table 2.

The cause-and-effect analysis as in Table 02 shows that the slow rate of growth of corporate sukuk in Indonesia can be dissected into three phases of the problem to conical to the root finding of the problem. Three phases of causation is and also the root of the problem can be described as follows:

The first stage problem is the findings as in Table 02 which are then reviewed in Table 03. From the supply side, the problems are mapped as 8 issues, the demand side 4 issues, and the regular side as many as 7 issues. Thus, the total problem of the slow growth rate of corporate sukuk in Indonesia is 19 problem.

The second stage of the problem is a more conical result of a total of 19 issues of slow growth in corporate sukuk in Indonesia. The results of this disarming resulted in 7 issues, namely: (i) concerns of potential double taxation; (ii) lack of understanding from investors; (iii) lack of understanding of the issuer; (iv) unparted investor base; (v) less liquid in the secondary market; (vi) very complex publishing documents; and (vii) the contract variation remains unclear.

The third stage of the problem is the causes of the second stage of the problem. When mapped, there are 5 issues that cause the second phase problem, the fifth is as follows:

The first problem is that there is still information about the requirements for the issuance of sukuk still asymmetric. This issue causes 3 issues, namely: (i) the existence of double tax concerns; (ii) lack of understanding from investors; and (iii) lack of containment from the issuer.

The second problem is the unavailability of supporting professions, and the third problem is the unavailability of supporting industries. Both of these issues cause two issues, namely: (i) unpaired investor base; and (ii) less liquid in the secondary market.

The fourth issue is the cost of an expensive publication, and the fifth issue is the complex sukuk structure. Both of these issues cause two issues, namely: (i) very complex publishing documents; and (ii) the variation of the contract is unclear.

The fourth stage problem is the final problem or the source of the problem, also called the root of the problem of the total 19 issues attached to the corporate sukuk in Indonesia. There are two root causes of sukuk growth rate in Indonesia, namely: (i) low socialization and education; and (ii) the limited human resources of capital market actors concerning sukuk.

Corporate Sukuk Development Strategy in Indonesia: Contribution to Literature. Nineteen issues of mapping analysis as in Table 1 and Table 2 are important findings which indicate that the sukuk market in Indonesia is failing to take advantage of domestic market potential and fail to capture global trends. The findings of this reinforces the results of the study of Fatah (2011), which suggests that although has potential and good prospects, the development of corporate sukuk in Indonesia is still very slow due to the problems inherent with market institutions Mapping the results in this study also reinforces what is stated by the OJK (2016), that the most prominent issue related to the development of sukuk in Indonesia is legal framework for the issuance of Islamic securities that is not strong yet.

The fundamental problem found in this study is the unclear sukuk regulations. According to Kurniawati (2015), it is necessary to formulate a standard of rules governing sukuk in order to provide clear and standard guidelines in accordance with the characteristics of sukuk as Sharia effect for both issuers and investors. According to Dewi (2011), still unclear regulation on sukuk is a reflection of still low Sharia capital market instruments. 
RJOAS, 2(74), February 2018

Table 2 - Mapping Analysis of Causes of Slow Rate of Corporate Sukuk Growth in Indonesia

\begin{tabular}{|c|c|c|c|c|}
\hline Categories & $\begin{array}{l}\text { Issues and Challenges of Sukuk Corporations } \\
\text { in Indonesia }\end{array}$ & $\begin{array}{l}\text { Issues That Become } \\
\text { the Factors }\end{array}$ & $\begin{array}{l}\text { Issues That Become } \\
\text { Causative Factors }\end{array}$ & Issues That Become Root Problem \\
\hline \multirow[b]{2}{*}{ Supply Side } & \multirow{2}{*}{$\begin{array}{l}\text { - There is still a lack of socialization and education } \\
\text { regarding contracts to investors } \\
\text { - } \quad \text { Variations in the contract and sukuk structure are } \\
\text { limited } \\
\text { - The existence of cost of funds } \\
\text { - } \quad \text { Related costs of issuance of sukuk } \\
\text { - The narrowness of information disclosure is still } \\
\text { - } \quad \text { required related to the issuance of sukuk } \\
\text { contracts to the issuer } \\
\text { VAT imposition constraints on the transfer of } \\
\text { beneficial rights to underlying assets } 1 .\end{array}$} & $\begin{array}{c}\text { Concerns of Double } \\
\text { Tax Potential } \\
\text { Lack of Understanding } \\
\text { from Investors }\end{array}$ & \multirow[b]{2}{*}{$\begin{array}{l}\text { Information Regarding } \\
\text { Requirement for Issuing Still } \\
\text { asymmetric Sukuk }\end{array}$} & \multirow{6}{*}{$\begin{array}{l}\text { Low Socialization and Education } \\
\text { The Limited Human Resources of } \\
\text { Capital Market Participants } \\
\text { Regarding Sukuk }\end{array}$} \\
\hline & & $\begin{array}{l}\text { Lack of Understanding } \\
\text { from Issuers }\end{array}$ & & \\
\hline \multirow[b]{2}{*}{$\begin{array}{l}\text { Demand } \\
\text { Side }\end{array}$} & \multirow{2}{*}{ 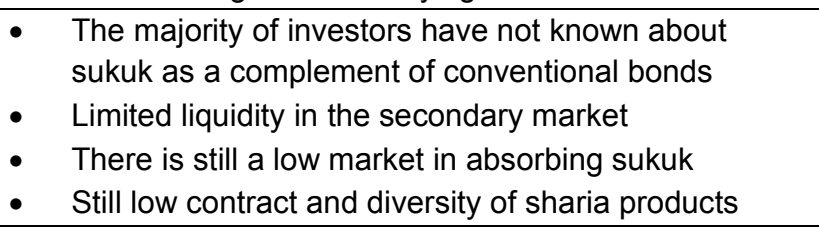 } & $\begin{array}{c}\text { Unmapped Base of } \\
\text { Investor }\end{array}$ & \multirow[b]{2}{*}{$\begin{array}{l}\text { Not yet Availability of Supporting } \\
\text { Profession } \\
\text { Not Available Supporting Industry }\end{array}$} & \\
\hline & & $\begin{array}{l}\text { Less Liquid in } \\
\text { Secondary Market }\end{array}$ & & \\
\hline \multirow[b]{2}{*}{$\begin{array}{l}\text { Regulatory } \\
\text { Side }\end{array}$} & \multirow{2}{*}{ 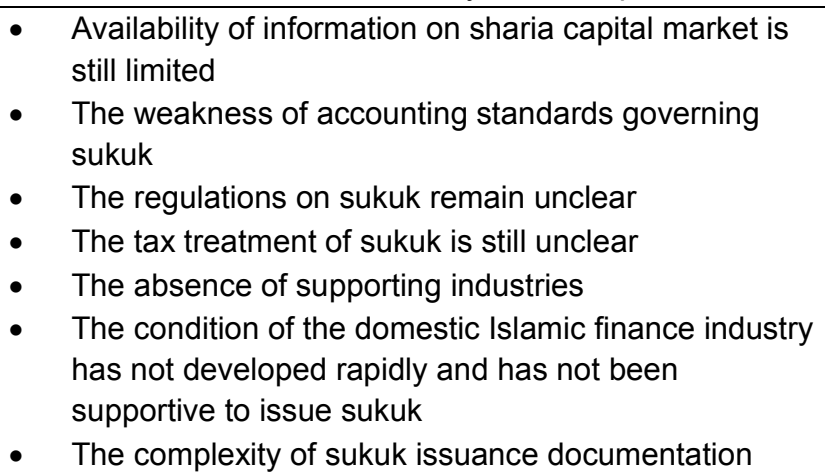 } & $\begin{array}{c}\text { Highly Complex } \\
\text { Publishing Document }\end{array}$ & & \\
\hline & & $\begin{array}{l}\text { Variations of } \\
\text { Agreement Still } \\
\text { Unclear }\end{array}$ & $\begin{array}{l}\text { Expensive Issuance Costs } \\
\text { Complex Sukuk Structure }\end{array}$ & \\
\hline
\end{tabular}

Source: Analysis Result, 2018. 
Unclear regulations on sukuk have implications on several issues such as limited liquidity in the secondary market. Park and Rhee (2006) suggest the importance of the development of investors, including foreign investors in order to make the sukuk market becomes more liquid because different types of investors tend to adjust their portfolios in the same direction at the same time. In addition, opening up local financial markets for foreign investors will generate high pressure and be able to modernize market infrastructure and maintain a high standard of transparency. While Haron \& Ibrahim (2012) suggest the importance of good governance as a strategy to ensure a liquid and dynamic sukuk market.

Unclear rules can also have implications for the low variety of contracts and sukuk structures. According Smaoui \& Nechi (2017), which varied sukuk structure is shown to have a positive impact on several things, including: (i) sukuk can mobilize savings and provide financing to the debtor in the long term, and is able to contribute to the efficient functioning of capital markets; (ii) the sukuk market is able to contribute to the deepening of financial markets; (iii) a well-developed sukuk market coupled with an advanced financial structure can stimulate economic growth through technological innovation and increase labor productivity in the private sector; (iv) sukuk certificates are based on risk sharing, which means that issuers and investors have investment risks and share profits or losses among them in accordance with the agreement. From some of the results of the study, the sukuk as a financial instrument indeed faced various types of risks, especially on the low variation of contract and sukuk structure that can be a potential inhibition for the growth of sukuk.

Another issue that is also important is investor base that has not been mapped. Therefore, according to Soemitra (2010), it is very important to do the restriction of investment zone and determine the type of financing agreement used in issuing sukuk. Based on the results of the questionnaire with the underwriters, the investor base is very important because it can open up the potential for sukuk absorption based on a wider investor network. According to Intana (2013), the development of investor base is very important in creating strategies to keep the market on an upward trend. Kurniawati (2015) recommends that the development of investor base needs to be done by establishing capital protection fund, Sharia capital market socialization and electronic arrangement of mutual fund securities. To obtain an optimal investor base, Sole (2008) suggests the importance of institutional investor diversity, including foreign investors. This can deepen the investor base of sukuk, modernize the sukuk market infrastructure, and be able to maintain a high standard of transparency.

Some of the above strategies are expected to have implications for the development of corporate sukuk in Indonesia. According to Zin et al (2011), the rapid development of sukuk is very important in transforming the now diversified economy by the encouraging private sector interest in sukuk. The advantage of the sukuk that triggered its rapid growth lies in its structure based on real assets (Ahmad, Daud \& Kefeli, 2012). This advantage minimizes the possibility of a financing facility that exceeds the value of the underlying asset of a sukuk transaction. The sukuk holder is entitled to the share of income generated from the sukuk assets in addition to the rights of the sale of the sukuk assets (Dewi, 2011). Some of these advantages should be utilized by minimizing the problems attached to corporate sukuk.

\section{CONCLUSION AND SUGGESTIONS}

The problems inherent in the development of corporate sukuk in Indonesia can be mapped into three sides, namely:

Problems from the supply side, namely: (i) the lack of socialization and education about the contracts to investors; (ii) variation of the contract and the structure of sukuk is still limited; (iii) the existence of cost of fund ; (iv) cost related to the issuance of sukuk; (v) supporting professions are not available; (vi) the narrowness of the required information disclosure related to the issue of $k$ tribe; (vii) socialization and education on contracts that is not optimal to issuers; and (viii) problems in imposition of VAT on the transfer of beneficial rights to underlying assets. 
The problems of demand side, namely: (i) the majority of investors have not known about sukuk as a complement of conventional bonds; (ii) liquidity in the secondary market is limited; (iii) still low market in absorbing sukuk; and (iv) the low level of contract and diversity of sharia products.

Issues from the regulation side, namely: (i) the availability of information on sharia capital market is still limited; (ii) accounting standards governing sukuk that is still weak; (iii) sukuk regulation is still unclear; (iv) taxation treatment on sukuk is still unclear; (v) supporting industries is not available; (vi) condition of domestic Islamic finance industry has not been growing rapidly and have support for issuing sukuk; and (vii) sukuk issuance documentation is still complex.

From the three classifications of sukuk development problems in Indonesia, the root of the problem can be divided into three phases. These three phases are at the root of the problem of sukuk growth inhibitor corporations in Indonesia. Each of the three phases is:

The issue the from first stage of supply side, a problem that is mapped as much as 8 issues, the demand 4 issues, and the regulatory side as much as 7 issue. Thus, the total problem of slow growth rate of corporate sukuk in Indonesia is 19 problem.

The second stage issues are: (i) concerns of potential double taxation; (ii) lack of understanding from investors; (iii) lack of understanding of the issuer; (iv) unparted investor base; (v) less liquid in the secondary market; (vi) very complex publishing documents; and (vii) the contract variation remains unclear.

The third stage of the problem is: (i) there is still information regarding the requirements of the issuance of sukuk still a symmetrical; (ii) professions has not been available; (iii) unavailability of supporting industries; (iv) costly issuance costs; (v) complex sukuk structures.

The fourth stage problem is the final problem or the source of the problem or also called the root of the problem , namely: (i) low socialization and education; and (ii) the limited human resources of capital market actors concerning sukuk.

Based on the explanation of mapping analysis and root problem analysis, the recommendations in this study refers to the explanation of the proposed development strategy, which consists of three priority suggestions, namely: (i) establish regulations on the supporting profession in the sukuk market; (ii) to make regulation of socialization and education on sukuk instruments; and (iii) providing supporting industries for the sukuk market. These three priority strategies can be executed through policy recommendations as follows:

Enhancing socialization and education on contracts of corporate sukuk.

Clarify the rules on corporate sukuk to reduce the complexity of sukuk issuance documentation and to enrich the variation of the contract and sukuk structure.

Establish the rules related to supporting institutions in sharia capital market and sharia securities companies.

Regulations related to sharia experts engaged in activities in the sukuk market. Therefore, sharia-related rules must be made in the capital market.

\section{REFERENCES}

1. AAOFI (Accounting and Auditing Organization for Islamic Financial Institutions). 2015. Shari'a Standard No.17 tentang Investment Sukuk. Uni Emirat Arab.

2. Abdo, Alaa. 2014. A Critical of the Sukuk Market, a Qualitative Study to Identify Current Risks and Opportunities. Dublin Business School.

3. Afif, M. 2014. Efektivitas sukuk vs obligasi konvensional. Rasaid, Vol. 1, No. 1, pp. 1-22.

4. Afshar, Tahmoures A. 2013. Compare and contrast sukuk (islamic bonds) with conventional bonds, are they compatible?. The Journal of Global Business Management, Vol. 9, No. 1, pp. 44-52.

5. Ahmad, N., Daud, S. N., \& Kefelia, Z. (2012). Economic forces and the sukuk

6. market. Procedia: Social and Behavioral Sciences, 65, 127-133. 
7. Ahmad, Nursilah; Daud, Siti Nurazina Mohd\& Kefeli, Zurina. 2012. Economic forces and sukuk market. International Congres on Interdisciplinary Business and Social Science, Social and Behavioral Sciences, No. 65, pp. 127-133.

8. Ascarya. 2010. The Development Of Islamic Financial System In Indonesia And The Way Forward", paper to be published as Occasional Paper, Bank Indonesia.

9. Bapepam. 2011. Siaran Pers Akhir Tahun 2012. Online: www.bapepam.go.id. Diakses: tanggal 13 Mei 2013. Jakarta: Departemen Keuangan Republik Indonesia.

10. Dewan Syariah Nasional. 2004. Fatwa No 41.DSN/MUI/IX/2004 Tantang Obligasi Syariah ljarah.

11. Dewi, Nila. 2011. Mengurai masalah pengembangan sukuk korporasi indonesia menggunakan analytic network process. TAZKIA, Islamic Finance\& Business Review, Vol. 6, No. 2, pp. 138-167.

12. Endri. 2007. Permasalahan Pengembangan Sukuk Korporasi di Indonesia Menggunakan Metode Analytical Network Process (ANP). Jurnal Keuangan dan Perbankan, Vol. 13, No. 3, pp. 359-372.

13. Fatah, Dede Abdul. 2011. Perkembangan obligasi syariah (sukuk) di indonesia: analisis peluang dan tantangan. Innovatio, Vol. X, No. 2, pp. 281-301.

14. Fatimatuzzahra, Vita. 2014. Reaksi pasar atas penerbitan sukuk (studi pada emiten saham penerbit sukuk periode 2008-2012). JESTT, Vol. 1, No. 5, pp. 363-378.

15. Hanefah, Mustafa Mohd; Noguchi, Akihiro\& Muda, Muhamad. 2013. Sukuk: global issues and challenge. Journal of Legal, Ethical and Regulatory Issues, Vol. 16, No. 1, pp. 107119.

16. Haron, Razali\& Ibrahim, Kahirunisah. 2012. The impact of sukuk on corporate financing: Malaysia evidence. Journal of Islamic Finance, Vol. 1, No. 1, pp. 1-11.

17. Hosen, Mosharrof. 2016. The pitfalls of the Malaysian sukuk industry: issues and challenges in practice. Research Gate, Working Paper.

18. IIFM. 2017. Sukuk Report: A Comprehensive Study Of The Global Sukuk Market

19. (6th ed.). Bahrain: Author.

20. Intana, Lila. 2013. Cara OJK menjaga market agar tetap bullish. Online: www.swa.co.id. (diakses pada tanggal 16 Juni 2013).

21. Jaffar, M. (2010). New Musyarakh model in managing Islamic investment. InternationalJournal of Islamic Finance, 2( 2), 25-36

22. Jarkasih, Muhammad\& Rusydiana, Aam Slamet. 2009. Perkembangan Pasar Sukuk: Perbandingan Indonesia, Malaysia, dan Dunia. Jurnal Bisnis dan Ekonomi: Antisipasi, Universitas Sanata Dharma, Vol. 1, No.2.

23. Kayo, E.K. and Kimura, H. (2011) Hierarchical Determinants of Capital Structure, Journal of Banking and Finance, 35, 358-371.

24. Kurniawati, Devi Dwi. 2015. Analisis Perkembangan Sukuk (Obligasi Syariah) dan Dampaknya Bagi Pasar Modal Syariah. Universitas Negeri Surabaya: Surabaya.

25. OJK. 2016. Roadmap Pasar Modal Syariah 2015-2019: Membangun Sinergi untuk Pasar Modal Syariah yang Tumbuh, Stabil, dan Berkelanjutan. Direktorat Pasar Modal Syariah Otoritas Jasa Keuangan: Jakarta.

26. OJK. 2015. Kajian Faktor-faktor yang Mempengaruhi Penawaran dan Permintaan Sukuk. Direktorat Pasar Modal Syariah OJK: Jakarta.

27. Park, D. and Rhee, C. (2006), "Building infrastructures for the Asian bond markets: settlement and credit rating", Asian Bond Markets: Issues and Prospects, BIS Papers No. 30, Bank for International Settlements, Basel, pp. 202-21.

28. Pasar Modal Syariah. 2018. Data Perkembangan Pasar Modal Syariah Per April 2017.

29. Purwaningsih, S. 2013. Faktor yang mempengaruhi rating sukuk yang ditinjau dari faktor akuntansi dan non-akuntansi. Accounting Analysis Journal, Vol. 2, No. 3, pp. 360-368.

30. Putri, Rianda A.A. 2015. Pengaruh penerbitan sukuk ijarah terhadap return on assets, return on equity dan earning per share emiten di bursa efek Indonesia tahun 2009-2013. JESTT, Vol. 2, No. 6, pp. 459-472. 
31. Rusydiana, Aam. 2012. Analisis Penguraian Masalah Pengembangan Sukuk Korporasi di Indonesia Pendekatan Metode ANP (Analytic Network Process). Online: www.Konsultananp.blogspot.com. (Diakses pada tanggal 29 Mei 2013).

32. Saad, Noriza Binti Mohd; Mamat, Mohd Noor Bin;\& Mohammad, Nor Edi Azhar Binti. 2014. Do sukuk issuance's characteristicshave a relation to yields and weighted average cost of capital in Malaysian capital market?. Australian Journal of Basic and Applied Sciences, Vol. 8, No. 12, pp.47-55.

33. Saeed,A\& Salah, O. 2014. Development of sukuk: pragmatic and idealist approaches to sukuk structures. J.I.B.L.R., Issue 1, pp. 41-52.

34. Setyani Dwi Lestasi, Endri, 2013. The Effects of Financial Performance to Corporate Sukuk Ratings in Indonesia. The 2nd IBSM, International Conference on Business and Mangement, 2 - 4 October 2013, Chiang Mai - Bangkok

35. Siskawati, Eka. 2010. Perkembangan obligasi syariah di Indonesia: suatu tinjauan. Jurnal Akuntansi dan Manajemen, Vol. 5, No. 2, pp. 01-09.

36. Smaoi, Houcem\& Nechi, Salem. 2017. Does sukuk market development spur economic growth?. Research in International Business and Finance, Vol. 41, pp. 136-147.

37. Soemitra, Andri. 2010. Bank dan Lembaga Keuangan Syariah. Kencana Media Grup: Jakarta.

38. Sole, Juan. 2008. Prospects and challenges for developing corporate sukuk and bond markets, lessons from a Kuwait case study. International Journal of Islamic and Middle Eastern Finance and Management, Vol. 1, No. 1, pp. 20-30.

39. Tariq, Ali Arsalan. 2004. "Managing Financial Risks Of Sukuk Structures", dissertation , Degree of Masters of Science at Loughborough University, UK.

40. Utaminingsih, Sri. 2008. Perlakuan Perpajakan Atas Transaksi Obligasi Syariah (Sukuk) Ijarah. Jurusan Akuntansi, Fakultas Ekonomi dan IImu Sosial, Universitas Islam Negeri Syarif Hidayatullah: Jakarta.

41. Zaheer, Sajjad\& Wijnbergen, Sweder J.G. 2013. Sukuk defaults: on distress resolution in Islamic finance. Tinbergen Institute Discussion Paper, TI 13-087/VI/DSF 57.

42. Zakaria, Nor Balkish; Isa, Mohamad Azwan\& Zainal, Rabiatul Alawiyah Abidin. 2012. The construct of sukuk, rating and default risk, Procedia, Social and Behavioral Sciences, Vol. 65, pp. 662-667.

43. Zin, M.Z.M; Sakat, A.A; Ahmad N.A; Nor, M.RM; Bhari, A; Ishak, S;\& Jamain, M.S. 2011. The effectiveness of sukuk in Islamic finance market. Australian Journal of Basic and Applied Science, Vol. 5, No. 12, pp. 472-478.

44. Zulkhibri, Muhamed. 2015. A synthesisof theoretical and empirical research on sukuk. Borsa Istanbul Review, Vol. 15, No. 4, pp. 237-248. 